\title{
Вежбе изговора фрранцуског самогласника [у] у савременим методама за учење француског језика до нивоа А2: могућности примене у настави са србофроним субјектима
}

Бранко М. Ракић*

Универзитет у Београду, Филолошки фракултет, Катедра за романистику Кључне речи:
француски
самогласник [у]
перцепција гласова
продукција гласова
корективне технике

\section{Апстракт}

У овом раду, најпре ћемо из перспективе артикулаторне фонетике говорити о француском самогласнику [у] и његовим изговорним карактеристикама. Затим ћемо укратко подсетити на истраживања и закључке до којих су наши аутори дошли у вези са тим како србофони субјекти перципирају, односно продукују француски самогласник [у]. После овог фонетског увода, анализираћемо три савремене француске методе за учење француског језика до нивоа А2 како бисмо, најпре, упоредили колико места у њима аутори посвећују вежбама за корекцију изговора француског самогласника [у], чија продукција говорницима српског језика представља значајан проблем. Затим ћемо анализирати типове вежби које су у њима елабориране за рад на корекцији овог самогласника и на крају да ли аутори дају објашњења о његовој артикулацији, као и специфична упутства и вежбе за његову коректну продукцију, намењене говорницима словенских, па самим тим и српског језика. У завршном делу овог рада, изнећемо предлоге како би могле да изгледају специфичне вежбе за кориговање погрешног изговора француског самогласника [у] у раду са србофоним субјектима. Ове специфичне вежбе елаборираћемо према савременим начелима фонодидактике француског језика и сходно сопственом искуству у настави фонетике француског језика са нашим студентима. (примљено: 28. априла 2021; прихваћено: 21. јуна 2021) www.anali.fil.bg.ac.rs

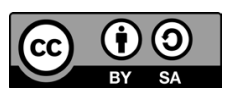

Филолошки факултет Катедра за романистику Студентски трг 3 11000 Београд, Србија joliepuce11@yahoo.fr 


\section{1. Увод}

У првом делу овог рада дескриптивном методом приказаћемо карактеристике француског самогласника [у] и објаснити разлоге због којих га наши студенти погрешно продукују као самогласник [u] односно [i]. У вези са разлозима за ово погрешно продуковање указаћемо и на појам „фонолошко сито“ који је у науку о језику тридесетих година 20. века увео Николај Трубецкој.

Средишњи део рада чини анализа три савремене француске методе за учење француског језика до нивоа А2. Приликом ове анализе, пажњу ћемо најпре усмерити на то колико места заузимају фонетска вежбања посвећена корективном раду на правилној продукцији француског самогласника [у], затим на поређење типова вежби које су елабориране за рад на корекцији овог самогласника и на крају на то да ли ученицима који припадају словенској језичкој породици аутори дају специфична објашњења како се овај глас артикулише, као и упутства и вежбе за његову коректну продукцију.

У закључку овог рада, а на основу врста вежбања које смо констатовали у методама, и на основу њихове прилагођености или недовољне прилагођености србофоним субјектима, изнећемо и предлоге конкретних вежби за кориговање погрешног изговора француског самогласника [у] посебно конципираних за рад са нашим ученицима. Предлоге могућих специфичних корективних артикулаторних техника у настави са србофоним субјектима засноваћемо на савременим начелима фонодидактике француског језика према којима правилној продукцији гласова страног језика нужно претходи њихова правилна перцепција, на техникама које су развили француски дидактичари, на закључцима наших аутора који су се бавили упоредним фонетским истраживањима француског и српског гласовног система (Гудурић, 1997; 2004; 2009), Шотра (2006), као и на сопственим запажањима и закључцима до којих смо дошли у настави фонетике француског језика и практичном корективном раду са нашим студентима.

\section{2. Артикулационе карактеристике француског самогласника [у]}

Француски самогласник [у] одликује се израженом затвореношћу и предњом артикулацијом, то јест твори се у предњем делу уста, као већина француских оралних самогласника, будући да се од дванаест оралних самогласника њих осам артикулише на предњем непцу.

Може се рећи да овај самогласник у себи сједињује артикулациона својства затворених француских самогласника [u] и [i]. Наиме, приликом творбе самогласника [y], уста су заобљена као приликом изговора самогласника [u], али се притом језик више не налази у задњем делу уста и није подигнут задњим делом ка меком непцу, већ се помера напред и повијеним врхом додирује зубе доње вилице, као приликом артикулације самогласника [i].

Из ове „двојаке“ артикулације у односу на артикулаторна својства српских самогласника проистичу и проблеми са којима се приликом изговора француског самогласника [у] сусрећу србофони субјекти на почетном, али и вишим нивоима учења, што је сасвим природно и разумљиво јер овај самогласник не постоји у гласовном систему српског језика. 


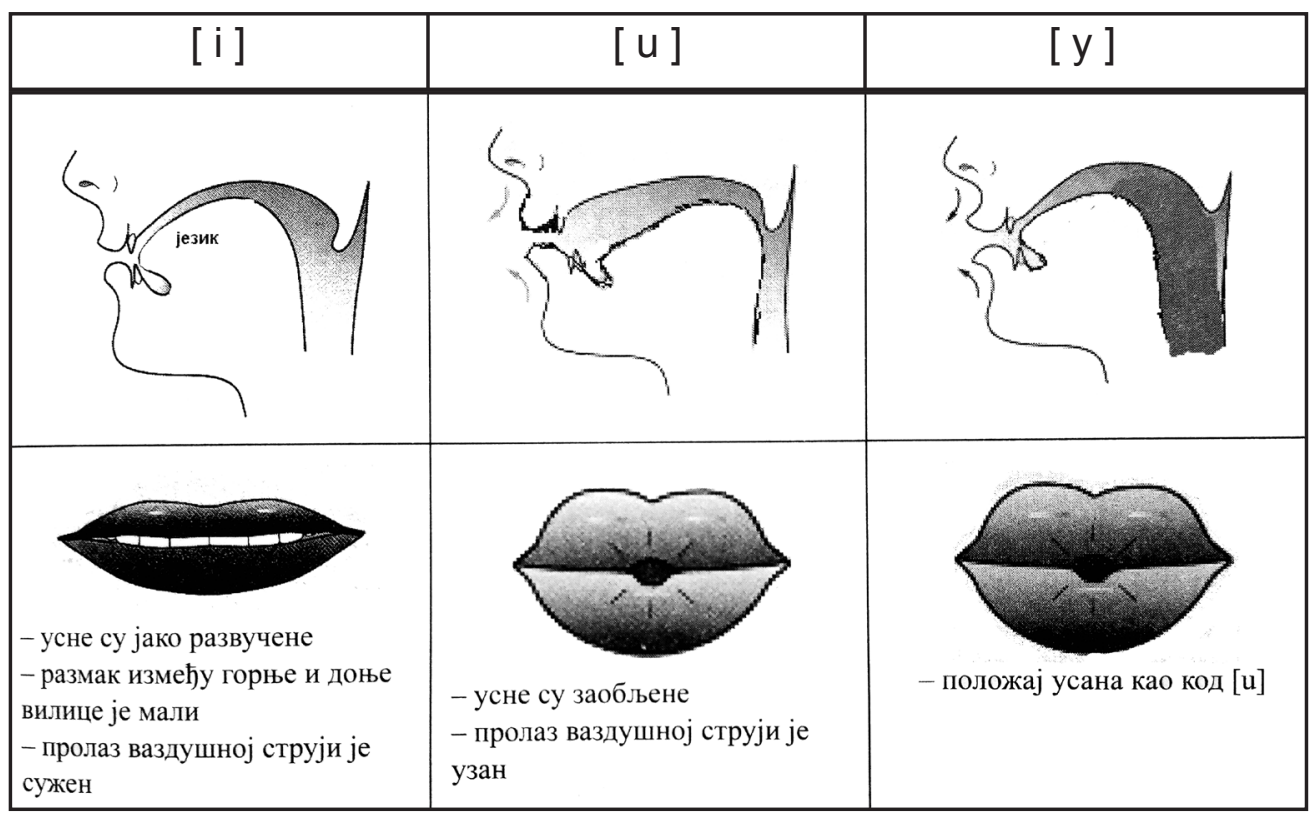

Слика 1. Положај уста и језика приликом артикулације француских самогласника [i], [u] и [у] (Гудурић, 2009: 63)

О појави да глас који не постоји у његовом матерњем језику, ученик најчешће не може одмах да продукује како треба, те да ће га заменити гласом који постоји у гласовном систему његовог матерњег језика, а који подсећа на дати глас из страног језика, говори још почетком 20. века, француски фонетичар Паси (Passy, 1922: 2-3), а ову појаву је, недуго затим, Николај Трубецкој (Troubetzkoy, 1949) објаснио појмом „фонолошког cuma“ (le crible phonologique).

Виђење које примат даје активном слушању које би требало да доведе до правилне продукције, у наставној пракси прво је примењено у оквиру аудио-оралне методе четрдесетих година 20. века, да би га шездесетих и седамдесетих година заступали Петар Губерина (Guberina, 1965) и француски поборници његове АВГС методе (Аудиовизуела-глобалноструктурална метода) и вербо-тоналне методе у фонетској корекцији међу којима треба истаћи Ренара (Renard, 1977). После периода комуникативног приступа у којем је рад на фонетској корекцији занемарен услед теоријске поставке да у центру пажње треба да буде ученик и његова комуникација, а не учење садржаја, фонетска корекција у савременим дидактичким приступима настави француског језика доживљава препород средином деведесетих година када Елизабет Лот (Lhote, 1995) уводи концепт познат као „звучни пејзаж“ у којем на значају поново добија активно слушање пре продукције страног језика, а ради навикавања ученика на „звучни пејзаж“ страног језика.

У савременим методама за учење француског језика које почивају на принципу еклектичности, то јест, комбиновања тековина свих досадашњих дидактичких метода, као и на акционом приступу, приступ фонетској корекцији заснован је на тековинама АВГС методе Петра Губерине (Guberina, 1965) и принципу да 
рад на правилном перципирању и идентификовању одређених сегменталних (гласова) или супрасегменталних елемената (акценат, ритам, интонација) мора да претходи раду на њиховој правилној продукцији, јер ако ученик погрешно чује неки глас неминовно ће га погрешно и продуковати.

Међутим, правилно перципрање одређеног гласа не гарантује неминовно и његову ваљану продукцију.

Када је конкретно у питању перцепција и продукција француског самогласника [y] код говорника српског језика, овде бисмо истакли резултате истраживања до којих су дошли наши аутори који су се бавили упоредним истраживањима француског и српског гласовног система. У опсежном истраживању које је спровела са десет генерација студената прве године француског језик и књижевности на Филозофском факултету у Новом Саду, у периоду од 1988. до 1998. године, Снежана Гудурић (Gudurić, 2009: 278-279) на основу анализе звучног корпуса износи закључак да је 95-100\% испитаника правилно перципирало француски самогласник [у] у различитим гласовним низовима. С друге стране, у фази продукције, проценат студената који су погрешно продуковали овај самогласник (као српско [u] или [i]) током понављања одређеног звучног записа, односно читања задатог исказа, био је изузетно висок: 22,33\% у случају слушног, односно 21\% у случају писаног стимулуса. Слично истраживање, само са децом узраста од 7 до 10 година, спровела је Вера Илијин (Ilijin in Gudurić, 2009: 279-280). Приликом анализе снимака понављања звучног стимулуса, Илијин је констатовала да 67,5\% деце погрешно продукује француски самогласник [у], или као српско [u] или као српско [i]. До истих закључака дошла је и Шотра (2006: 82-83) у истраживању спроведеном на корпусу снимака студената (од прве до четврте године студија) француског језика Филолошког факултета у Београду. У њиховој продукцији француског самогласника [у], Шотра констатује да, код студената прве и друге године, долази до високог процента грешке, те да га једна трећина студената продукује као [i], да га мање од трећине њих продукује као [u], а да се код неких јавља дифтонгална реализација [yu.

Имајући у виду резулатате ових истраживања, намеће се закључак да је са србофоним субјектима неопходно радити на проширењу њихове артикулационе базе и стицању нових изговорних навика, те да је врло битно да наставник процес корекције отпочне упућивањем ученика у начин артикулације француског самогласника [у] кроз објашњења и графичке приказе положаја одређених делова говорног апарата током фонације овог гласа.

3. Анализа вежби изговора француског самогласника [у] у савременим француским методама за учење француског језика до нивоа А2

У овом делу рада, анализираћемо три савремене француске методе за учење франуског језика до нивоа A2 (Nickel 1, Tendances A1/A2 и Édito A1/A2), a представићемо их према редоследу објављивања. Ове методе одабрали смо јер су намењене почетним нивоима учења француског језика, на којима је рад на стицању изговорне компетенције најважнији будући да, без њега, може доћи до фосилизације, то јест укорењавања погрешног изговора и јер на најбољи начин 
репрезентују извесну маргинализацију рада на фонетској корекцији приметну у методама за учење француског језика објављеним у последње две деценије ${ }^{1}$.

При њиховој анализи, пажњу ћемо најпре обратити на то какав корективни приступ у њима доминира, затим на начин на који су елабориране изговорне вежбе у којима се обрађује изговор француског самогласника [у] и на крају да ли аутори дају било каква артикулаторна објашњења и упутства за коректну продукцију овог самогласника која би могла да помогну у раду са говорницима српског језика.

На самом почетку, значајно је истаћи да је у свим методама присутан исти принцип за који се залажу сви значајнији дидактичари који се баве фонетском корекцијом од деведесетих година 20. века па до данас као што су Селс-Мурсија (Celce-Murcia, 1996), Шампањ-Мизар и Бурдаж (Champagne-Muzar, Bourdages, 1998) и Лоре (Lauret, 2007), а који своје зачетке налази у радовима Пасија (Passy, 1922), Губерине (Guberina, 1965), Моник и Пјера Леона (Léon, Léon, 1964) и других: у корективном раду периципирање увек треба ставити испред продукције.

Тако, рад на развоју фонетске компетенције у овим методама увек почиње вежбама у којима је тежиште најпре на вежбама дискриминације и идентификације, а затим и слушања и понављања одређених супрасегменталних (акценат, ритам, интонација) или сегменталних (гласови) карактеристика француског језика.

У свим методама које овде анализирамо примењен је овакав принцип рада, а приметићемо $и$ то да се најпре обрађују интонативни обрасци и прозодијске карактеристике француског језика као што је акценат који се реализује дужењем вокала у последњем слогу ритмичке групе (ритмичка група = синтагма), а који представља основу ритмичке организације француског исказа, а затим и француски гласови који могу представљати проблем ученицима.

Занимљиво је још истаћи да овакав редослед рада почива на методолошким оквирима за које су се залагали заговорници АВГС методе још шездесетих и седамдесетих година 20. века.

У методи за учење француског језика Tendances A1, рад на дискриминацији гласа [у] у односу на [u] и [i] своди се на једно вежбање на почетку књиге. Циљ вежбања је да ученик увиди разлику између три наведена гласа и да их затим коректно понови.

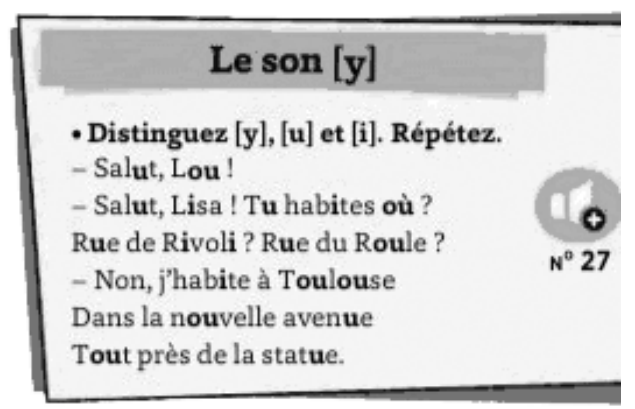

Слика 2. Пример вежбања из методе Tendances A1 (Girardet et al., 2016: 26)

1 Поред метода које ћемо овде приказати, у изради рада консултовали смо и следеће методе француских издавача: Le Nouveau Taxi 1, 2; Alter Ego A1, A2; Écho A1, A2. 
Све до краја методе, глас [у] појављује се у свега неколико реченица у склопу фонетских вежбања, па ученик није у прилици да овај глас више увежбава и подсвесно фиксира. Аутори не дају никакве информације о томе како се овај глас артикулише, ни у виду објашњења о положају појединих делова говорног апарата, нити у виду графичког приказа говорног апарата, на којем би се могло видети да се француски самогласник [у] одликује израженом лабијализацијом, затвореношћу и предњом артикулацијом. Поред тога, не дају ни упутства на шта би, ради коректне продукције овог гласа, морали да обрате пажњу ученици који припадају појединим језичким породицама, у нашем случају словенској језичкој групи. ${ }^{2}$

У другом делу ове методе, Tendances A2, гласови [y], [u] и [i] обрађују се поново само на почетку, у првој лекцији. Вежбање приказано на слици 3 подразумева слушање и понављање исказа у којима се истовремено појављују и глас [y] и глас [u] или глас [i] и глас [у].

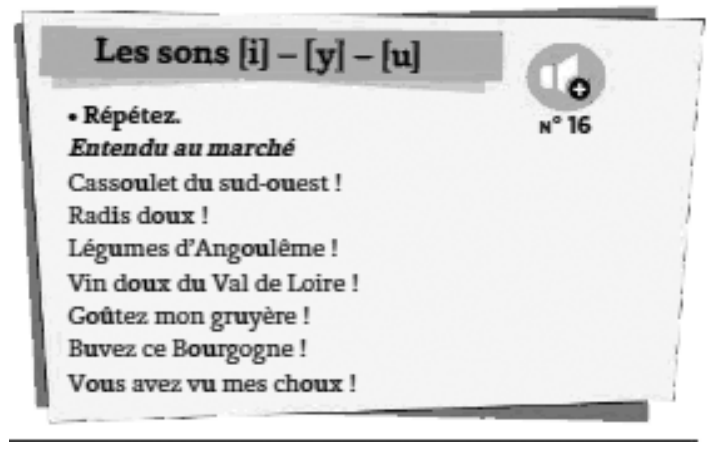

Слика 3. Пример вежбања из методе Tendances A2 (Girardet et al., 2016: 25)

Исти је случај и са радном свеском која је у склопу ове методе, па се рад на усвајању француског самогласника [у] своди на једно вежбање у којем је тежиште на идентификацији гласова [y], [u] и [i] и у којој се од ученика не захтева понављање исказа који се налазе у вежби.

На основу наведених примера, можемо закључити да приступ фонетској корекцији аутора метода Tendances A1/A2 одговара општем начелу које влада у савременој дидактици страних језика: пре било каквог понављања исказа у којима се налази глас или гласови чији коректан изговор треба усвојити, ученици слушају и раде вежбе дискриминације и идентификације одређених гласова.

С друге стране, не постоје било какве напомене које би помогле ученику да увиди како се ови гласови артикулишту, а изузетно мали број вежбања посвећен је увежбавању француског самогласника [у]. Самим тим, уколико профе-

2 Аутори су до краја пажњу више посветили изговорним проблемима са којима се сусрећу ученици којима је матерњи језик шпански, немачки или енглески, па је тежиште на фонетским вежбама дискриминације и понављања сугласника $[\mathrm{s}] /[3],[\mathrm{k}] /[\mathrm{g}],[\mathrm{f}] /[\mathrm{v}]$ и [s]/[z]. 


\section{Oral}

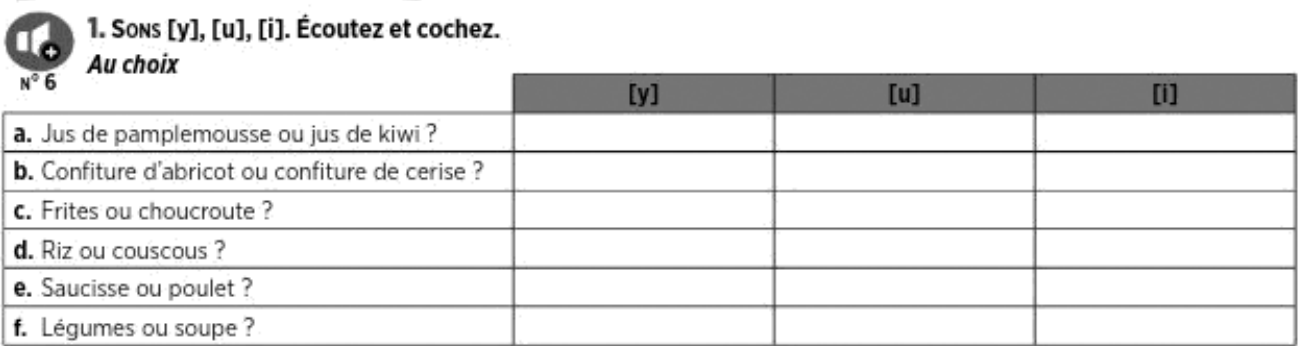

Слика 4. Пример вежбања из радне свеске Tendances A2, Cahier d'activités (Girardet et al., 2016: 15)

сор детаљније не упути ученика у артикулаторне карактаристике овог француског самогласника и са̂м не припреми додатне вежбе, велика је могућност да ученици неће усвојити коректан изговор овог гласа.

У методи Nickel 1, аутори рад на самогласнику [у] почињу тек у лекцији 5, и то тако што га уводе кроз вежбе дискриминације и идентификације заједно са самогласницима [u] и [i]. Тако, на страни 73 у првој вежби у којима су заступљени минимални парови (у овом случају два исказа који се разликују само по једном гласу), ученици треба да кажу да ли чују реченицу под а) или под б) и да ли чују глас [i] као у речи ville, глас [у] као у речи rue или глас [u] као у речи tour:

1. a) Il est sûr.

b) Il est sourd.

2. a) Prenez cette roue.

b) Prenez cette rue.

3. a) Il dit tout.

b) Il dit «tu».

4. a) C'est un lit.

b) C'est un loup.

5. a) Tu vas bien?

b) Tout va bien?

6. a) Ma rue est belle.

b) Marie est belle.

У другој вежби, ученици треба поново да саслушају исте реченице, затим да разврстају речи у зависности од тога да ли чују [y], [u] или [i]. После тога се прелази на вежбе продукције у којима треба да их понове и да кажу која графија одговара сваком од три наведена гласа.

У трећем вежбању, које је поново вежба дискриминације и идентификације, од ученика се захтева да каже колико пута чује глас [у] у наредним реченицама:

1. Muriel dit qu'elle arrive samedi à midi.

2. Arthur! Où es-tu ?

3. Vous êtes sûrs que Julie est partie?

4. Tu as dit «deux » ou "douze »?

5. Il est sûr de réussir. (Augé et al., 2014: 73) 
Ни у овој методи, аутори не дају никаква објашњења о артикулацији самогласника [у], нити графичке приказе положаја делова говорног апарата током његове артикулације. Поред тога, не дају никаква специфична упутства ученицима који припадају појединим језичким породицама.

Када је у питању вежбанка која прати ову методу, примећујемо исти принцип рада са тежиштем на вежбама дискриминације и идентификације гласа [у] у односу на гласове [u] и [i]. Као и у самој методи, продукцији гласа [у] посвећено је врло мало пажње, само једно вежбање, колико је места дато и увежбавању начина како се који од гласова [y], [u] и [i] пише.

\section{[ii]-|y\}-[u]}

fcoutez et soulignez le mot que vous entendez.
1. pour $\bullet$ pur $\bullet$ pire
5. sourd • sûr • cire
2. nid $\bullet$ nu $\bullet$ nous
6. lu $\bullet$ lourd $\bullet$ lys
3. si • sur $\bullet$ sous
7. ri $\bullet$ rue $\bullet$ roue
4. mou • mue • mie
8. dis $\bullet$ du $\bullet$ doux

Ecoutez les phrases et classez les mots suivants selon qu'ils contiennent un des sons : [i], [y], [u].

autoroute $\bullet$ Toulouse $\bullet$ bouchée $\bullet$ ville $\bullet$ musée $\bullet$ Aquitaine $\bullet$ pharmacie $\bullet$ sur $\bullet$ avenue $\bullet$ touristes $\bullet$ visitent $\bullet$ monuments $\bullet$ l'église $\bullet$ brasserie

\begin{tabular}{|l|l|l|}
\hline [i] & [y] & [u] \\
\hline & & \\
\hline
\end{tabular}

3 Écoutez et dites si les phrases que vous entendez contiennent ou non le son [y].

\begin{tabular}{|c|c|c|}
\hline & oui & non \\
\hline 1 & & \\
\hline 2 & & \\
\hline 3 & & \\
\hline 4 & & \\
\hline 5 & & \\
\hline 6 & & \\
\hline
\end{tabular}

\section{Écoutez et répétez chaque phrase.}

Écoutez et complétez la transcription.

1. $M \_$riel d $t$ qu'elle arr_ve samed à $m \_d$.

2. Arth_r! _es-t_?

3. $V \_s$ êtezs_rs que J_les est part_?

4. T__ as d_t " deux" ou "d_ze " ?

5. _l est s_rderé_ss_r.

Слика 5. Пример вежбања из радне свеске Nickel 1 (Augé et al., 2014: 73)

Као и у случају метода Tendances A1/A2, може се констатовати да је у елаборирању фонетских вежбања, испоштовано начело да вежбе дискриминације и идентификације гласа или гласова чији коректан изговор треба усвојити претходе вежбама понављања датих гласова, а у циљу њиховог правилног перципирања.

С друге стране, аутори се ничим не дотичу артикулације гласова [y], [u] и [i], а минималан број вежбања посвећен је продукцији самогласника [у], па је мало 
вероватно да наши ученици могу да овладају коректним изговором самогласника [у] уколико професор не припреми и додатна артикулаторна појашњења и фонетска вежбања посвећена овом гласу.

Последња метода коју ћемо анализирати је Édito A1, у којој је самогласнику [у] посвећена већа пажња, па се, у лекцији 5, овај глас обрађује у односу на гласове са којима га говорници српског језика мешају приликом продукције: глас [i] и глас [u].

Аутори ове методе придржавају се начела да вежбе перципирања и правилног идентификовања гласова треба да претходе њиховој продукцији, па од ученика захтевају (слика 6) да пажљиво саслушају изговор гласова [у] и [i] у одређеним речима и да посматрају како су наведене речи написане. Затим се од њих тражи да саслушају исказе и најпре кажу у којој речи чују глас [у] односно [i], а потом да исте те исказе поново саслушају како би проверили своје одговоре, и на крају да наведене исказе и понове.

\section{PHONÉTIQUE Les sons [i]/[y] IÉCHAUFFEMENT \\ 1 a Écoutez le son [i] et le son [y] et observez les mots. \\ a $\mid$ dix $\mathbf{b} \mid$ mur \\ b Écoutez. Dans quels mots vous entendez le son [i]? \\ Dans quels mots vous entendez le son [y] ? \\ c Réécoutez pour vérifier vos réponses à l'activité $1 \mathrm{~b}$. Puis répétez les mots.}

\section{FONCTIONNEMENT}

2 Complétez à l'aide de la transcription p. 205.

- Le son [i] peut s'écrire .....

Exemples : dix,

- Le son [y] peut s'écrire

Exemples: mur,

\section{ENTRAÎNEMENT}

3 Écoutez et répétez les phrases.

4 À vous ! Faites une liste de mots d'une syllabe et de deux syllabes qui contiennent le son [i] ou le son [y]. Ensuite, jouez avec votre voisin(e) : il/elle dit un mot d'une syllabe qui contient le son [i], vous répondez avec un autre mot d'une syllabe qui contient le son [i]. Et c'est votre tour.

Exemple : - prix

- dire ; nature

- voiture...

Слика 6. Пример вежбања из методе Édito A1 (Alacaraz et al., 2016: 80)

Поред тога, значајно је истаћи да аутори настоје да обогате понекад монотоне фонетске вежбе у којима исказе понавља сваки ученик појединачно, па у вежби 4 предлажу интеракцију између ученика који треба да саставе спискове једносложних или двосложних речи у којима се јављају гласови [y] и [i], да затим један од њих изговори једносложну реч у којој се налази глас [i] или [у], а да ученик поред њега затим каже неку другу реч са истим гласом. 


\title{
54 Page 80, Exercice 1b et c
}

\begin{abstract}
a Rémi aime la musique. - b II est six heures et demie, je pars du bureau. - c la lecture est une activité intéressante - d Le matin, je jardine. - e Le soir, nous nous occupons des enfants.
\end{abstract}

\section{Page 80, Exercice 3}

\section{a Il est dix heures moins dix, je bricole. - b II est midi et demi, je fais la lessive. - c l'après-midi, je suis occupé. - d Il y a une réunion au bureau. - e Vite ! ma voiture !}

Слика 7. Транскрипт вежбања из методе Édito A1 (Alacaraz et al., 2016: 205)

Исти принцип рада констатујемо и на сликама 8 (вежбе) и 9 (транскрипт датих вежбања) на којима се може видети како је обрађен глас [у], овог пута у односу на глас [u]. За разлику од претходних вежбања, аутори овде пажњу више посвећују и графијама које у писаном језику одговарају наведеним гласовима.

Ни у овој методи нису дате никакве информације о начину артикулисања самогласника [y], [u] и [i] нити специфична упутства за рад са ученицима који припадају појединим језичким групама, у нашем случају словенској језичкој породици.

На крају ћемо напоменути да у методи Édito A2, аутори не дају никаква фонетска вежбања за корекцију изговора француског самогласника [у].

Изузимајући донекле методу Édito A1, заједнички недостатак свих метода које смо анализирали је што је увежбавању правилног изговора француског самогласника [у] посвећено изузетно мало места, једно, евентуално два вежбања, што свакако није довољно да коректним изговором овог гласа овладају ученици који га немају у фонолошком систему матерњег језика. Поред тога, ни у једној од метода које смо анализирали није објашњен нити визуелно приказан положај делова говорног апарата приликом артикулације француских гласова [у], [u] и [i], што би могло да буде од значајне помоћи ученицима, нити су изнети предлози у вези са начином рада са ученицима који глас [у] погрешно продукују као [u] или као [i].

Такође, свим анализираним методама заједничко је и да њихови аутори не дају никаква појашњења нити упутства на шта би, ради правилног изговора овог гласа, наставници морали да обрате пажњу у раду са говорницима српског језика. 


\section{PHONÉTIQUE Les sons [y]/[u]}

\section{ÉCHAUFFEMENT}

1 a Écoutez le son [y] et le son [u] et observez les mots.

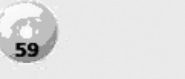

a | sur

b | sous

b Écoutez. Dans quelles paires les mots sont identiques? Dans quelles paires

les mots sont différents?

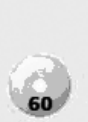

60

c Écoutez. Vous entendez le son [y] dans quels mots ? Vous entendez le son [u] dans quels mots ?

\begin{tabular}{|c|c|}
\hline [y] & [u] \\
\hline$\ldots . .$. & $\ldots . .$. \\
\hline
\end{tabular}

d Réécoutez pour vérifier vos réponses à l'activité 1c. Puis répétez les mots.

\section{FONCTIONNEMENT}

2 a Complétez à l'aide de la transcription p. 206. Le son $[u]$ peut s'écrire .....

b Trouvez d'autres exemples de mots qui Exemples : sous, ............ contiennent le son [y] et de mots qui contiennent

Rappel : le son [y] peut s'écrire le son [u].

\section{ENTRAÎNEMENT}

3 Dictée ! Écoutez et écrivez. Puis lisez la transcription p. 206 pour vérifier.

4 À vous ! Écrivez deux phrases avec au moins deux mots qui contiennent le son [y] et deux mots qui contiennent le son [u]. Ensuite, lisez ces deux phrases à votre voisin(e). Votre voisin(e) écrit ces deux phrases et vous vérifiez.

Слика 8. Пример вежбања из методе Édito A1 (Alacaraz et al., 2016: 86)

\section{Page 86, Exercice 1b}

a tu/tout - b nous/nous - c vous/vu - d rue/roue - e du/doux - f jus/ jus

\section{Page 86, Exercice 1c et d}

a Je visite un musée. - b On se retrouve à quelle heure ? - c On pourrait se voir. - d Prends un pull !

\section{Page 86, Exercice 3}

a Allô Matthieu ? Salut ! - b Coucou Paul ! - c Marylou et toi, vous voulez venir au restau avec nous ce soir ? - d Pourquoi pas ? Et après, nous pouvons aller au cinéma. - e $0 \mathrm{k}$, je peux consulter le programme si tu veux. À plus tard ! - $\mathrm{f}$ À tout à l'heure.

Слика 9. Транскрипт вежбања из методе Édito A1 (Alacaraz et al., 2016: 206)

\section{4. Предлози специфичних корективних стратегија у раду са србофо- ним субјектима \\ Како се констатације какве смо управо изнели у закључном делу анализе француских метода за учење француског могу изнети и у вези са већином ак- туелних метода за учење француског језика, настојаћемо да изнесемо сугестије,}


предложимо смернице и изнесемо конкретне примере специфичних корективних стратегија које се могу применити у раду са србофоним субјектима на почетним нивоима учења француског језика, а у вези са изговором самогласника [у].

Наставник би ученицима требало да објасни на који начин се овај глас артикулише, да им, прибегавајући артикулаторним схемама (слика 1) укаже, с једне стране, на положај појединих делова говорног апарата током артикулације француског самогласника [y], а с друге, током артикулације гласова [u] и [i] са којима га наши ученици приликом продукције мешају.

Будући да вежбе које за циљ имају правилно периципирање одређених проблематичних гласова треба да претходе вежбама продукције, нагласили бисмо и овде да корективни рад треба почети вежбама дискриминације и идентификације. Овај тип вежбања може бити у виду минималних парова, то јест речи које се разликују само по једном гласу, на пример, у случају гласова [у], [u] и [i]: pur / pour / pire; rue / roue / ri; mue / moue / mie.

У вези са овим видом вежбања, Лоре (Lauret, 2007: 104) примећује да професор треба да састави вежбе са минималним паровима, водећи притом рачуна да се гласови који се обрађују најпре нађу у наглашеном (последњем) слогу ритмичке групез , затим у првом слогу и на крају у средини ритмичке групе. Дакле, у случају минималних парова са самогласницима [y], [u] и [i], а имајући у виду наведене сугестије, могли бисмо предложити следећи пример вежби дискриминације:

Il bute

Butez-vous

Vous butez

\section{- $\quad$ Il boute}

- Boutez-vous

- Vous boutez

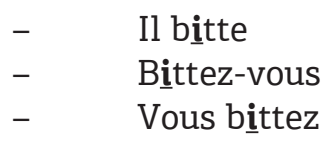

- $\quad$ Il bitte

- $\quad$ Vous bittez

У случају наших ученика/студената, при избору речи које се јављају у минималним паровима, требало би водити рачуна и о томе у каквом се гласовном окружењу налази самогласник [у].

Као Канеман-Пугач и Педоја-Гембретјер (Kaneman-Pougatch, PedoyaGuimbretière, 2003: 7), повољно гласовно окружење Лоре назива олакшавајућим контекстима (Lauret, 2007: 109-114), а за ученике који француски самогласник [y] продукују као [u] препоручује да овај глас буде окружен сугласницима [s], [z], [t], [d], [n], па наводи примере: su [sy], tu [ty], du [dy], nu [ny], suce [sys], Suze [sy:z], tune [tyn], dune [dyn] (Lauret, 2007: 113).

Француски дидактичари Лоре (Lauret, 2007: 105) и Лебел (Lebel in Lauret, 2007: 113-114) препоручују и да се у овакавим вежбама прибегава логатомима, то јест, једносложним или двосложним сегментима без значења како би се ученици сконцентрисали искључиво на карактеристике гласова чијим изговором треба да овладају, а не на значење речи које понављају.

Лебел (Lebel in Lauret, 2007: 113) тако у раду са ученицима који [у] продукују као [u] предлаже употребу логатома у којима је самогласник [у] у олак-

3 Искази се у француском језику ритмички организују у ритмичке групе које заправо одговарају подели на синтагме. Акценат се налази на последњем слогу ритмичке групе и реализује се дужењем самогласника, прим. аут. 
шавајућем контексту окружен гласовима [s, t, z], али и [f, 3], како у вежбама дискриминације и идентификације тако и у фази продукције:

$\begin{array}{lll}{[\mathrm{ys}]} & {\left[\int \mathrm{y}\right]} & {[\mathrm{sys}]} \\ {[\mathrm{yt}]} & {[\mathrm{ty}]} & {[\mathrm{syt}]} \\ {[\mathrm{yz}]} & {[3 \mathrm{y}]} & {[\mathrm{syz}]} \\ {[\text { tys }]} & {\left[\int \mathrm{ys}\right]} & {[\mathrm{zys}]} \\ {[\text { tyt }]} & {\left[\int \mathrm{yt}\right]} & {[\mathrm{zyt}]}\end{array}$

Лебел (Lebel, 1991: 145) затим препоручује и да се глас [у] нађе на крају реченице са узлазном интонацијом и по могућству у отвореном слогу, као на пример у реченицама Où vas-tu ? или Que fais-tu ?.

Овде је приметан утицај Ремона Ренара, представника вербо-тоналне методе фонетске корекције у Француској, који је седамдесетих година 20. века препоручивао оптимализацију окружења путем интонације, то јест прибегавање интонацији у олакшавању правилне перцепције одређених гласова. У раду са ученицима који [у] изговарају као [u] препоручивао је да се глас [у] нађе на крају узлазне интонације као у реченици C'est votre voiture ? (Renard, 1977: 75). Таква интонација истиче, наиме, артикулаторну напетост и високе фреквенције овог самогласника које ученици не перципирају.

У раду са студентима француског језика, уверили смо се да је ово једна од најделотворнијих стратегија у корекцији погрешне продукције самогласника [у]. Наиме, студенти који имају потешкоћа у правилној продукцији овог самогласника, изјавну реченицу Tu vas. углавном изговоре као [tuva]. Међутим, одмах затим, када им се пусти снимак упитног исказа Où vas-tu ?, студенти, углавном, коректно изговоре исказ као [uvaty]. У таквим ситуацијама, требало би од студената тражити да одмах иза реченице Où vas-tu ? изговоре такође упитни исказ Tu vas où ? или Que fais-tu ? $\rightarrow$ Tu fais quoi ? или Où es-tu ? $\rightarrow$ Tu es où ? како би се искористио повољни изговорни контекст и фиксирала коректна изговорна навика.

Као врло честе вежбе у фази продукције, то јест понављања, бројни аутори препоручују минималне парове. Оне могу бити истог типа као вежбе са минималним паровима у фази дискриминације о којима смо већ говорили, где се проблематични гласови јављају углавном у изолованим речима, али могу бити и у виду контраста унутар исте реченице: C'est dessous ou dessus ?; Tu es sûr que tu es sourd ?, или у виду контраста између две различите реченице: C'est tout vu ! / C'est tout vous !; C'est un début / C'est un des bouts (Lauret, 2007: 107).

Као могуће корективне стратегије, Лебел (Lebel, 1991: 146) још препоручује да се прибегне вежбама убрзавања темпа говора и постепеног нијансирања, то јест, постепеног преласка у изговору са гласа [u] ка гласу [i] како би се ученику скренула пажња да за артикулацију гласа [y] треба заоблити уста, али и померити језик напред као приликом артикулације [i]. Поред тога, требало би радити и на визуелној сензибилизацији ученика на артикулационе карактеристике гласа [у] путем приказивања артикулаторних схема (слика 1) и описа његове артикулације. 
Овде бисмо посебно скренули пажњу на оно што би требало избегавати у вежбама на самом почетку фазе понављања у раду са србофоним субјектима. Наиме, током практичног рада са нашим студентима који француски самогласник [у] продукују као [u] констатовали смо да им посебну тешкоћу у изговору представљају једосложне речи где ликвиде [R] и [1] претходе гласу [y], као на пример у исказима:

Il a un rhume et il fume. - Avec un rhume, il ne fume pluss. - Si, il fume de plus en plus! (Charliac et al., 2003: 47).

Приликом изговора речи rhume, plus и fuте, наиме, студенти који имају проблема са изговором гласа [у] изговарају га без изузетка као [u], док смо код оних који постепено овладавају коректном артикулацијом самогласника [y] приметили да наведени самогласник правилно продукују у речи fume, али га такође изговоре као [u] у речима rhume и plus.

Закључак да би у почетку фазе продукције приликом одабира примера за понављање требало избегавати речи у којима ликвиде [R] и [l] претходе гласу [y] засновали смо на овој опсервацији, али и на оном што смо уочили после упутства да студент наведене исказе изговори без наведених ликвида, дакле: Il a un ...ume et il fume. - Avec un ..ume, il ne fume p.us. - Si, il fume de p.us en p.us!. Наиме, у наведеним исказима у којима су ликвиде изостављене, већина њих успела би коректно да продукује глас [у]. Даљим вежбањем, а после дватри понављања исказа без ликвида, студенти би на крају успешно и коректно изговорили самогласник [у] у исказима у њиховом почетном виду, са ликвидама $[\mathrm{R}]$ и $[1]$.

У случају да се глас [y] погрешно продукује као [u], посебну пажњу би требало посветити описивању сегмента који недостаје како би се глас [y] коректно продуковао, то јест, померању језика напред толико да врх језика додирује секутиће доње вилице.

Из досадашње праксе увидели смо да оваква објашњења могу да доведу до забуне и блокаде услед покушавања да се споји заобљеност усана и постављање језика у предњи део уста, па се као веома делотворно упутство показао сликовитији опис Ежена Гуриоа (Gourio, 1921: 145), с почетка 20. века, према којем усне треба истурити као приликом звиждука и затим зазвиждати. Ученику, дакле, треба сугерисати да зазвижди и обрати пажњу на положај језика приликом звиждука који је, заправо, истоветан као приликом артикулације француског самогласника [y].

Као још једну од могућих корективних техника у раду са србофоним субјектима који имају проблема са продукцијом француског самогласника [у], скренули бисмо пажњу и на поступак који предлаже Снежана Гудурић. Наиме, наша ауторка (Гудурић, 2009: 69-70) констатује да, будући да се карактерише предњом артикулацијом, француски глас [у] изазива палатализацију сугласника коју му претходи, па препоручује да се покуша са умекшаним изговором су- 
гласника који претходи гласу [y], као у паровима: tout - tu; doux - du; coup - cul; goût - Gustave у којима су гласови [t, d, k, g] у првим речима веларизовани (услед гласа [u] који долази иза њих, а који се твори на тврдом непцу), а у другим палатализовани.

Лебел (Lebel, 1991: 147) у раду са ученицима који самогласник [у] продукују као [i] предлаже да се у логатомима глас [у] нађе у олакшавајућем контексту са гласовима [b, m, v], али и [, 3$]$.

Затим, као повољан интонативни контекст препоручује да се глас [у] јави на крају силазне интонативне кривуље (Lebel, 1991: 147) у чему се поново, очигледно, инспирише Ренаром (Renard, 1977: 75) који је као пример наводио изјавни исказ „Oui, c'est ma voiture.“, где се [у] налази на крају силазне интонације која поспешује опуштену артикулацију и у први план истиче ниже фреквенције овог гласа.

Лебел (Lebel, 1991: 146), потом, препоручује вежбе постепеног нијансирања, али овде постепеног преласка у изговору са гласа [i] ка гласу [u] (како би се ученику скренула пажња на усне које су изузетно заобљене приликом артикулације гласа [у]), затим вежбе успоравања темпа говора и изговарања кроз шапат слога у којем се налази глас [y].

Ученике/студенте који глас [у] погрешно продукују као [i] треба упутити у артикулационе карактеристике гласа [у] путем приказивања артикулаторних схема (слика 1), а посебну пажњу би требало посветити чињеници да су усне током артикулације француског самогласника [i] изузетно развучене, те да је за коректну продукцију гласа [у] неопходно веома заоблити и истурити усне.

Лебел (Lebel, 1991: 148) овде предлаже тип вежбања којем смо често прибегавали у пракси и који се у раду са нашим студентима показао врло ефикасним. Наиме, студенту треба рећи да најпре полако, а затим све брже и брже усне покреће из развученог положаја који одговара гласу [i] у изузетно заобљени и истурени положај у којем усне треба дуже да задржи, а који је каракетеристичан за изговор француског гласа [у] док предавач одговарајућим покретима лица и усана треба да представља модел. Као наставак овог вида вежби, предложили бисмо понављање исказа у којима се јављају оба гласа, и то најпре са два гласа [i] на почетку и једним [у] на крају, а затим са једним гласом [i] на почетку и два гласа [у] на крају, као на пример: je n'y vis plus; je n'y ris plus; je n'y trie plus; / je n'y sue plus; je n'y mue plus; je n'y crus plus.

Као закључак нашем раду, напоменули бисмо да кључну улогу у фонетском корективном раду имају професори и њихов правилан одабир најподеснијег начина рада и најрелевантнијих типова вежбања.

Они би требало да током фазе корекције обрате посебну пажњу на то каква се одступања јављају у изговору код ученика/студената, те да затим примене корективне технике о којима смо говорили, елаборирајући притом посебне „персонализоване“ вежбе за оне који глас [y] продукују као [u], односно као [i] или адаптирајући и допуњујући вежбања у уџбеницима које користе у настави. 


\section{Литература}

Гудурић, С. (1997). Артикулациона база и учене језика. Контрастивна студија на примерима вокалских система франиуског и српског језика (необјављена докторска дисертација). Филозофски факултету Универзитета у Новом Саду.

[Gudurić, S. (1997). Artikulaciona baza i učenje jezika. Kontrastivna studija na primerima vokalskih sistema francuskog i srpskog jezika (neobjavljena doktorska disertacija). Filozofski fakultet Univerziteta u Novom Sadu]

Гудурић, С. (2004). O природи гласова. Београд: Завод за уџбенике.

[Gudurić, S. (2004). O prirodi glasova. Beograd: Zavod za udžbenike]

Гудурић, С. (2009). Основи фонетике с фонологијом франиуског језика. Београд: Завод за уџбенике.

[Gudurić, S. (2009). Osnovi fonetike s fonologijom francuskog jezika. Beograd: Zavod za udžbenike]

Gudurić, S. (2009). La base articulatoire et le crible phonologique. Le cas de sujets serbophones. Filološki pregled, 36(2), 275-283.

Šotra, T. (2006). Kako progovoriti na stranom jeziku. Beograd: Zavod za udžbenike.

Celce-Murcia, M. (1996). Teaching pronunciation: a reference for teachers of English to speakers of other languages. Cambridge: Cambridge University Press.

Champagne-Muzar, C., Bourdages, J. (1998). Le point sur la phonétique. Paris: CLE international.

Charliac, L. et al. (2003). Phonétique progressive du français avec 400 exercices (niveau débutant). Paris: CLE International.

Gourio, E. (1921). The Direct Method of teaching French. Boston/New York/Chicago/San Francisco: Houghton Mifflin Company.

Guberina, P. (1965). La méthode audio-visuelle structuro-globale. Revue de phonétique appliquée, 1, 35-64.

Kaneman-Pougatch M., Pedoya-Gumbretière E. (2003). Plaisir des sons. Paris: Didier.

Lauret, B. (2007). Enseigner la prononciation du français: questions et outils. Paris: Hachette.

Léon, M. (2003). Exercices systématiques de prononciation française. Paris: Hachette. Léon, P., Léon, M. (1964). Introduction à la phonétique corrective. Paris: Hachette.

Léon, P. (1998). Phonétisme et prononciation du français. Paris: Nathan.

Lebel, J.-G. (1991). Fiches correctives des sons du français. Québec: Université Laval.

Lhote, É. (1995). Enseigner l'oral en interaction. Paris: Hachette.

Passy, P. (1922). Petite phonétique comparée des principales langues européennes (3e Édition). Leipzig/ Berlin: B. G. Teubner.

Renard, R. (1977). Introduction à la méthode verbo-tonale de correction phonétique. Paris: Didier.

Troubetzkoy, N. (1949). Principes de phonologie. Paris: Klincksieck. 


\section{Методе за учење француског језика}

Alacaraz, M. et al. (2016). Édito A1. Paris: Didier.

Alacaraz, M. et al. (2016). Édito A2, Paris: Didier.

Augé, H. et al. (2014). Nickel 1. Paris: CLE International.

Augé, H. et al. (2014). Nickel 1, Cahier d'activités. Paris: CLE International.

Berthet, A. et al. (2012). Alter Ego A1. Paris: Hachette.

Berthet, A. et al. (2012). Alter Ego A2. Paris: Hachette.

Capelle, G., Menand, R. (2008). Le nouveau Taxi 1. Paris: Hachette

Girardet, J. et al. (2016). Tendances A1. Paris: CLE International.

Girardet, J. et al. (2016). Tendances A2. Paris: CLE International.

Girardet, J. et al. (2016). Tendances A2, Cahier d'activités. Paris: CLE International.

Girardet, J., Pécheur, J. (2013). Écho A1. Paris: CLE International.

Girardet, J., Pécheur, J. (2013). Écho A2. Paris: CLE International.

Menand, R. (2009). Le Nouveau Taxi 2. Paris: Hachette.

\section{Branko M. Rakić}

Résumé

LES EXERCICES DE PRONONCIATION DE LA VOYELLE FRANÇAISE [Y] DANS LES MÉTHODES DE FRANÇAIS CONTEMPORAINES JUSQU'AU NIVEAU A2: POSSIBILITÉS D'APPLICATION DANS LE TRAVAIL CORRECTIF AVEC LES SUJETS SERBOPHONES

Dans l'introduction de cet article, nous avons abordé la question des caractéristiques articulatoires de la voyelle française [y]. Puis, nous avons fait un bref rappel de plusieurs recherches menées par des auteurs serbes et de leurs conclusions respectives sur la perception et la production de cette voyelle par les serbophones. Après cette introduction phonétique, nous avons analysé trois méthodes de français contemporaines (jusqu'au niveau A2) afin d'y comparer: 1) l'importance accordée par leurs auteurs respectifs aux exercices de prononciation et de correction de la voyelle française [y], dont la production pose beaucoup de problèmes aux sujets serbophones; 2 ) les types d'exercices élaborés pour la correction phonétique de cette voyelle en vue de sa production optimale et 3) si leurs auteurs respectifs donnent des explications sur l'articulation de cette voyelle, ainsi que des conseils articulatoires et des exercices spécifiques à l'usage des apprenants slaves. En nous appuyant sur les conclusions de cette analyse, nous avons formulé des propositions d'exercices spécifiques destinés aux apprenants serbophones et à la correction de leur prononciation de la voyelle $[y]$. Ces exercices spécifiques, nous les avons élaborés selon les principes 
de la phonodidactique d'aujourd'hui, mais aussi à partir de notre expérience dans l'enseignement de la phonétique du français et dans le travail correctif avec les étudiants serbes.

\section{Mots-clés:}

voyelle française [y], perception des sons, production des sons, techniques spécifiques de correction articulatoire

Summary

THE FRENCH VOWEL [y] PRONUNCIATION EXERCISES IN CONTEMPORARY FRENCH LEARNING METHODS UP TOA2 LEVEL: POSSIBILITIES OF APPLICATION IN CORRECTIVE WORK WITH SERBIAN-SPEAKING SUBJECTS

In this paper, we first discuss the French vowel [y] and its pronunciation characteristics from the perspective of articulatory phonetics. We then briefly review the research and conclusions reached by Serbian authors on how Serbian-speaking subjects perceive or produce the French vowel [y]. After this phonetic introduction, we analyze three modern French methods for learning French up to the A2 level, primarily in order to compare how much space the authors devote to exercises for correcting the pronunciation of the French vowel [y]. The production of this vowel is a significant issue for Serbian speakers. We then analyze the types of exercises that focus on the correction of the French [y]. Finally, we examine whether the authors give explanations about its articulation, as well as specific instructions and exercises for its correct production intended for speakers of Slavic languages, including Serbian. In the final part of this paper, we suggest some novel exercises aimed at correcting the wrong pronunciation of the French vowel [y], which could be used with Serbian-speaking students. These were designed following modern principles of phonodidactics of French and are based on our own experience in teaching French phonetics to Serbian students.

\section{Key words:}

French vowel [y], sound perception, sound production, corrective techniques 